\title{
PEMAHAMAN MENGENAI DIET GLUTEN FREE CASEIN FREE (GFCF) SERTA PENERAPANNYA PADA ANAK AUTIS TINGKAT SEKOLAH DASAR SLB C YAKUT PURWOKERTO
}

\author{
AN UNDERSTANDING ABOUT GLUTEN-FREE CASEIN-FREE \\ DIET (GFCF) AND ITS APPLICATION IN AUTISM CHILDREN IN \\ SPECIAL NEED SCHOOL C YAKUT PURWOKERTO
}

\author{
Yukika Fatmalasari, Hery Winarsi, Dyah Umiyarni Purnamasari \\ Prodi Ilmu Gizi FIKes Universitas Jenderal Soedirman \\ E-mail : winnieyukika@yahoo.co.id
}

\begin{abstract}
The objective of this study was to access an understanding about Gluten-Free Casein-free Diet $(G F C F)$ and its application in autism children in special need school C Yakut Purwokerto. This study uses qualitative research methods, descriptive depth interviews with 6 key informants and 11 informants support. The results showed that the mother initially did not understand and know about the GFCF diet. After got information from therapy, physician, psychologist and school teacher, they understanding of GFCF diet with is proved by mothers already know what foods must be limited. But the mother has not been able to implement a GFCF diet in everyday life as evidenced by the child is still often eat foods made from flour and milk. This is also evidenced in the form Food Frequency Quetionnaire Qulitative. Mother's level of understanding about the GFCF diet has been good, but from the 6 main informant could not do GFCF diet properly and strictly.
\end{abstract}

Keywords: Autism, Diet Gluten Free Casein Free, Flour and milk

\begin{abstract}
ABSTRAK
Sekitar $60 \%$ penyandang autis mempunyai gangguan sistem pencernaan akibat alergi makanan. Gangguan sistem pencernaan ini mengakibatkan terjadinya kebocoran usus (Leaky Gut). Dampak leaky gut pada autis menyebabkan produksi hormon sekretin terhambat. Sebagai akibat, protein susu sapi (casein) dan gandum (gluten) tidak dapat dicerna dengan sempurna, karena protein tersebut tidak berubah menjadi asam amino tetapi menjadi peptida yang seharusnya dibuang lewat urin, akan tetapi pada anak autis peptida ini diserap kembali oleh tubuh dan masuk ke otak dan diubah oleh reseptor opioid menjadi morfin. Untuk itu anak autis harus membatasi asupan makanan dari gluten dan kasein, agar tidak membuat anak hiperaktif dan tantrum. Tujuan penelitian ini adalah mengetahui gambaran pemahaman ibu mengenai diet GFCF serta sejauh mana ibu menerapkan diet tersebut pada anaknya. Penelitian ini menggunakan metode penelitian kualitatif, jenis deskriptif dengan wawancara mendalam kepada 6 informan utama dan 11 informan pendukung. Hasil menunjukkan bahwa ibu pada awalnya tidak memahami dan mengetahui mengenai diet GFCF. Setelah mendapatkan informasi dari terapi, dokter, psikolog dan guru sekolah ibu menjadi paham
\end{abstract}


mengenai diet GFCF dengan dibuktikan ibu sudah mengetahui makanan apa saja yang harus dibatasi. Namun ibu belum bisa menerapkan diet GFCF di kehidupan sehari-hari yang dibuktikan dengan anak masih sering mengonsumsi makanan berbahan dasar tepung dan susu. Hal ini juga dibuktikan dalam form Food Frequency Quetionnaire (FFQ) Qulitative. Tingkat pemahaman ibu mengenai diet GFCF sudah baik, namun dari 6 informan utama belum bisa melakukan diet GFCF dengan baik dan secara ketat.

Kata Kunci : Autis, Diet Gluten Free Casein Free, tepung dan susu

\section{PENDAHULUAN}

Kasus autis tidak hanya terjadi di negara-negara maju tetapi juga di negara berkembang seperti Indonesia. Prevalensi autis di dunia saat ini mencapai 15-20 kasus per 10.000 anak. Jumlah anak penderita autis di Indonesia diperkirakan mencapai 150.000-200.000 anak (Priyatna, 2010). Sekitar $60 \%$ penyandang autis mempunyai gangguan sistem pencernaan akibat alergi makanan. Gangguan sistem pencernaan ini mengakibatkan terjadinya kebocoran usus (Leaky Gut). Dampak leaky gut pada autis menyebabkan produksi hormon sekretin terhambat. Hormon tersebut berfungsi merangsang produksi enzim pencernaan dari pankreas. Sebagai akibat, protein susu sapi (casein) dan gandum (gluten) tidak dapat dicerna dengan sempurna, karena protein tersebut tidak berubah menjadi asam amino tetapi menjadi peptida yang seharusnya dibuang lewat urin, akan tetapi pada anak autis peptida ini diserap kembali oleh tubuh dan masuk ke otak dan diubah oleh reseptor opioid menjadi morfin (Ratnawati, 2003).

$$
\text { Judarwanto }
$$

menjelaskan bahwa gangguan saluran cerna yang berkepanjangan dapat mengganggu fungsi otak yang akhirnya mempengaruhi perkembangan dan perilaku anak. Gangguan fungsi otak dapat menyebabkan timbul gangguan perkembangan dan perilaku anak seperti gangguan hiperaktivitas, emosi, perkembangan motorik, tidur malam, konsentrasi sehingga memperberat gejala autis. Anak autis yang mengalami gangguan perilaku terkait dengan gangguan pencernaan 
disarankan untuk menjalani diet Gluten Free Casein Free (GFCF).

Latifah (2004) menambahkan bahwa $68,42 \%$ anak autis di Kota Bogor yang diberi diet GFCF mengalami perbaikan perilaku terutama dalam hal hiperaktivitas. Namun, terkadang para orangtua, terutama ibu-ibu masih banyak yang tidak mengetahui jenis-jenis makanan yang termasuk dalam kelompok GFCF. Adanya berbagai pantangan dalam makanan bagi autis, maka dibutuhkan pemahaman ibu tentang pengaturan diet yang tepat. Peran ibu di dalam kelurga selain mengasuh anak juga berperan penting dalam pendampingan proses perkembangan anak termasuk dalam hal pemilihan makanan yang sesuai dengan kebutuhan anak (Ramadayanti, 2012).

Menurut Purwanto (2006)
terdapat beberapa faktor yang
mempengaruhi kepatuhan orang tua
dalam menerapkan terapi diet GFCF,
diantaranya faktor demografi,
pengetahuan, komunikasi terapi, sikap,
dan dukungan keluarga. Pemahaman
orang tua yang rendah maka tingkat
kepatuhannya dalam menerapkan diet

GFCF juga rendah. Memiliki pemahaman mengenai kebutuhan gizi anak autis maka ibu dapat menyusun pola makan yang sesuai bagi anaknya, sehingga diharapkan status gizi anaknya dalam keadaan baik/normal (Mashabi dan Tajudin, 2009). Oleh karena itu peneliti bertujuan menggali pemahaman mengenai diet GCFC serta penerapannya pada anak autis tingkat sekolah dasar SLB C Yakut Purwokerto.

\section{METODE PENELITIAN}

Penelitian ini menggunakan pendekatan deskriptif dengan metode kualitatif. Lokasi penelitian di SLB C Yakut Purwokerto dan rumah orangtua anak autis. Subyek penelitian terdiri dari 2 jenis yaitu informan utama (ibu dari anak autis) dan informan pendukung (bapak atau anggota keluarga dekat dan guru kelas). Jumlah sampel penelitian yaitu 6 informan utama dan 11 informan pendukung.
Pemilihan sampel secara sengaja (purposive sampling) yaitu pemilihan sampel dilakukan dengan cara responden bersedia berpartisipasi 
dalam penelitian dan responden merupakan ibu kandung dari anak autis, bapak atau anggota keluarga dekat dengan, dan guru kelas di SLB C Yakut Purwokerto yang mengajar anak autis yang menjadi subjek penelitian tersebut. Teknik pengumpulan data dengan teknik snowball sampling yaitu tidak berdasarkan pada jumlah sampel namun dilakukan berdasarkan saat tidak ditemukannya lagi variasi informasi makan penelitian dihentikan dan sudah selesai. Validitas dan reliabilitas menggunakan cara triangulasi sumber yaitu melakukan cross-check kepada informan pendukung terkait hasil wawancara dengan informan utama. dan metode pengolahan data dengan 3 teknik yaitu reduksi data, model data dan verifikasi kesimpulan.

\section{HASIL DAN PEMBAHASAN}

\section{Karakteristik Umum Informan}

a. Informan utama

Tabel 1. Karakterstik Umum Informan Utama

\begin{tabular}{ccccc}
\hline No & Nama & $\begin{array}{c}\text { Usia } \\
\text { (Tahun) }\end{array}$ & $\begin{array}{c}\text { Pendidikan } \\
\text { Terakhir }\end{array}$ & Pekerjaan \\
\hline 1. & Informan Utama 1 & 29 & SMP & Pedagang \\
2. & Informan Utama 2 & 36 & SMA & Ibu Rumah Tangga \\
3. & Informan Utama 3 & 41 & SMP & Ibu Rumah Tangga \\
4. & Informan Utama 4 & 30 & SD & Ibu Rumah Tangga \\
5. & Informan Utama 5 & 37 & SD & Pedagang \\
6. & Informan Utama 6 & 41 & D3 & Guru \\
\hline
\end{tabular}

b. Informan pendukung (bapak atau anggota keluarga dekat)

Tabel 2. Karakteristik Umum Informan Pendukung

\begin{tabular}{ccccc}
\hline No & Nama & $\begin{array}{c}\text { Usia } \\
\text { (Tahun) }\end{array}$ & $\begin{array}{c}\text { Pendidikan } \\
\text { Terakhir }\end{array}$ & Pekerjaan \\
\hline 1. & Informan Pendukung 1 & 38 & SMA & Pedagang \\
2. & Informan Pendukung 2 & 36 & SMA & Swasta \\
3. & Informan Pendukung 3 & 46 & SMA & Swasta \\
4. & Informan Pendukung 4 & 30 & SD & Pedagang \\
5. & Informan Pendukung 5 & 43 & SD & Kuli \\
6. & Informan Pendukung 6 & 60 & SD & Ibu Rumah Tangga \\
\hline
\end{tabular}


c. Informan pendukung (guru kelas)

Tabel 3. Karakteristik Umum Informan Pendukung

\begin{tabular}{ccccc}
\hline No & Nama & $\begin{array}{c}\text { Usia } \\
\text { (Tahun) }\end{array}$ & $\begin{array}{c}\text { Pendidikan } \\
\text { Terakhir }\end{array}$ & $\begin{array}{c}\text { Guru } \\
\text { Kelas }\end{array}$ \\
\hline 1. & Informan Pendukung 1 & 35 & $\mathrm{~S} 1$ & $2 \mathrm{~A}$ \\
2. & Informan Pendukung 2 & 43 & $\mathrm{~S} 1$ & $4 \mathrm{~A}$ \\
3. & Informan Pendukung 3 & 28 & $\mathrm{~S} 1$ & $4 \mathrm{~B}$ \\
4. & Informan Pendukung 4 & 45 & $\mathrm{~S} 1$ & 5 \\
5. & Informan Pendukung 5 & 29 & $\mathrm{~S} 1$ & 2B \\
\hline
\end{tabular}

2. Pemahaman Ibu Mengenai Diet Gluten Free Casein Free (GFCF)

Tabel 4. Pemahaman Ibu Mengenai Diet Gluten Free Casein Free (GFCF)

\begin{tabular}{|c|c|c|}
\hline No & Pertanyaan & Informan Utama \\
\hline 1. & $\begin{array}{l}\text { Pengetahuan awal ibu } \\
\text { mengenai diet GFCF }\end{array}$ & $\begin{array}{l}\text { - Ibu pada awalnya belum mengetahui sama } \\
\text { sekali mengenai diet GFCF ini, sehingga ibu } \\
\text { memberikan makanan apa saja yang anak } \\
\text { inginkan tanpa adanya pantangan. }\end{array}$ \\
\hline 2. & Sumber informasi & $\begin{array}{l}\text { - Ellian Centre Terapi Purwokerto } \\
\text { - Psikolog Margono dan guru sekolah } \\
\text { - Metafora Terapi Purwokerto } \\
\text { - Orangtua murid di sekolah } \\
\end{array}$ \\
\hline 3. & $\begin{array}{l}\text { Pemahaman ibu mengenai } \\
\text { diet GFCF sekarang }\end{array}$ & $\begin{array}{l}\text { - Ibu membatasi pemberian makanan yang } \\
\text { berbahan dasar tepung seperti roti dan mie, } \\
\text { mengganti susu sapi dengan susu kedelai. } \\
\text { - Ibu masih memberikan mie, roti dan makanan } \\
\text { lain yang berbahan dasar tepung. Hal ini } \\
\text { dikarenakan sang anak selalu meminta } \\
\text { makanan tersebut dan akhirnya ibu tidak tega } \\
\text { jika tidak diberikan. } \\
\text { - Ibu memberikan susu sereal kepana anak, } \\
\text { karena anak sangat susah makan nasi atau } \\
\text { makan makanan berat lainnya. Sehingga } \\
\text { asupan utama anak adalah susu sereal saja } \\
\text { setiap harinya. }\end{array}$ \\
\hline
\end{tabular}

Dibuktikan dengan kutipan wawancara dengan salah satu informan pendukung yaitu : "Kalo sebelumnya belum tau sih yah harus dibatasin kayak gitu jadi makan apa aja yang penting sehat gitu anaknya." (Informan Pendukung 4 Bapak)
Berdasarkan wawancara mendalam dengan informan utama terkait pemahaman awal ibu mengenai diet GFCF didapatkan hasil bahwa pada awalnya ibu belum mengetahui sama sekali mengenai diet GFCF ini, sehingga ibu memberikan makanan apa saja yang anak mau dan suka. 
Berdasarkan hasil penelitian Mashabi NA dan Tajudin NR pada tahun 2009, diketahui bahwa tinggi rendahnya pemahaman ibu akan mempengaruhi pola makan anak autis. Penelitian Kusumayanti et al. tahun 2005 menyebutkan bahwa sebagian besar anak penyandang autis yang di terapi di RS Sanglah Denpasar belum dapat melaksanakan diet GFCF (Gluten Free Casein Free). Salah satu alasan yang dikemukan ibu dari penyandang autis adalah kurangnya pengetahuan ibu tentang diet GFCF (Gluten Free Casein Free) bagi anak autis.

Pada dasarnya, orangtua yang mengikuti terapi dalam frekuensi yang sering dan teratur memang memiliki pemahaman yang lebih mendalam dibanding orangtua yang hanya tau dari guru sekolah ataupun orangtua murid di sekolah. Ketika mengetahui ada keterlambatan dalam perkembangan anak yang diindikasikan sebagai ciri-ciri anak autis, maka langkah yang dapat dilakukan sangat bervariatif. Para orangtua dapat meminta pendapat orangtua lain yang memiliki anak autis. Selain hal tersebut orangtua juga dapat datang ke pusat-pusat terapi anak berkebutuhan khusus (anak autis). Hal lain yang dapat dilakukan adalah datang ke dokter, psikolog atau psikiater untuk memperoleh informasi yang pasti tentang perkembangan anaknya, sehingga pemahaman orangtua pun akan meningkat sesuai seberapa sering orangtua tersebut mendapatkan informasi (Yuwono, 2009). 


\section{Penerapan Diet Gluten Free Casein Free (GFCF)}

Tabel 5. Penerapan Diet Gluten Free Casein (GFCF)

\begin{tabular}{|c|c|c|}
\hline No & Pertanyaan & Informan Utama \\
\hline 1. & $\begin{array}{l}\text { Bekal dan jajan anak di } \\
\text { sekolah }\end{array}$ & $\begin{array}{l}\text { - Anak tidak pernah membawa bekal dari } \\
\text { rumah, namun jajan disekolah. } \\
\text { - Anak membawa bekal dari rumah dan suka } \\
\text { jajan juga disekolah dan jajanan yang sering } \\
\text { dikonsumsi adalah mie kemasan. } \\
\text { - Anak membawa bekal dari rumah dan tidak } \\
\text { pernah jajan disekolah, karena anak memang } \\
\text { tidak suka jajan atau makan makanan camilan. }\end{array}$ \\
\hline 2. & $\begin{array}{l}\text { Makanan yang sering } \\
\text { dikonsumsi dirumah dan } \\
\text { apakah adanya pembatasan } \\
\text { makanan dari tepung dan } \\
\text { susu }\end{array}$ & $\begin{array}{l}\text { - Anak setiap harinya makan masakan ibu } \\
\text { dirumah dan untuk menu makanan atau cara } \\
\text { penyajian tidak ada yang berbeda untuk } \\
\text { anggota keluarga lainnya. Makanan yang biasa } \\
\text { dimasak juga selalu ada sayur-sayuran. } \\
\text { - Belum diterapkannya secara penuh makanan } \\
\text { bebas gluten dan bebas kasein oleh ibu kepada } \\
\text { anak. } \\
\text { - Sebagian ibu hanya membatasi porsi dan } \\
\text { frekuensi pemberian makanan berbahan dasar } \\
\text { tepung dan susu. Dan masih ada sebagian ibu } \\
\text { yang masih memberikan makanan berbahan } \\
\text { dasar tepung dan susu atau tidak dilakukan } \\
\text { pembatasan. }\end{array}$ \\
\hline 3. & $\begin{array}{l}\text { Dampak positif setelah } \\
\text { membatasi makanan } \\
\text { berbahan dasar tepung dan } \\
\text { susu }\end{array}$ & $\begin{array}{l}\text { - Anak sudah berkurang sifat hiperaktifnya dan } \\
\text { dapat sosialisasi dengan temannya. } \\
\text { - Anak masih tidak dapat mengontrol emosinya } \\
\text { dan sering memberontak karena anak pun } \\
\text { masih sering mengonsumsi makanan berbahan } \\
\text { dasar tepung salah satunya adalah mie dalam } \\
\text { frekuensi yang sering. }\end{array}$ \\
\hline
\end{tabular}

Dibuktikan dengan kutipan wawancara dengan salah satu informan pendukung : "Kalo susu sih kayaknya udah full ngga dikasih, soalnya keliatan banget kalo susu keseringan dikasih itu langsung kayak emosinya sama aktifnya itu langsung meningkat. Jadi kita usahain buat ngga dikasih sama sekali. Sekarang udah ga dikasih susu, udah mulai bisa ke kontrol emosi nya gitu ngga hiperkatif lg." (Informan Pendukung 1 Bapak)

\section{Dengan beberapa informasi}

yang sudah didapat oleh ibu, maka dari itu pemahaman ibu saat ini sudah mengetahui makanan apa saja yang harus dibatasi. Namun pada dasarnya ibu merasakan belum melakukan diet GFCF dengan sepenuhnya. Jadi, yang ibu lakukan hanya mengurangi beberapa pemberian jenis makanan dari bahan dasar tepung dan susu saja. Namun ada juga ibu yang masih memberikan mie dan susu pada anak 
karena anak memang sulit makan sehingga ibu memberikan makanan yang disukai anak agar anak bisa makan. Hal ini yang akhirnya membuat kepatuhan ibu dalam melaksanakan diet GFCF ini kurang maksimal, dapat dibuktikan dengan kurangnya perhatian dan pengawasan ibu saat anak sedang jajan di sekolah maupun dirumah.

\section{Hasil Data Form Food Frequency Questionnaire (FFQ)}

Tabel 6. Hasil Data Form Food Frequency Questionnaire (FFQ)

\begin{tabular}{llrl}
\hline No & Frekuensi Konsumsi Makanan & \multicolumn{1}{c}{ Jenis Makanan } \\
\hline 1. & Makanan sering sekali $(>1 \mathrm{x}$ sehari $)$ & Kecap, roti, biskuit, crackers, kue. \\
\hline 2. & $\begin{array}{l}\text { Makanan } \\
(<3 \mathrm{x} / \text { minggu })\end{array}$ & kadang-kadang & Es krim, bihun, snack berbumbu. \\
\hline 3. & Makanan jarang $(<1 \mathrm{x} /$ minggu $)$ & $\begin{array}{l}\text { Mentega, makaroni, cokelat, seafood, } \\
\text { saus. }\end{array}$ \\
\hline 4. & Makanan Tidak Pernah & $\begin{array}{l}\text { Pasta, pizza, salad dressing, saus, } \\
\text { yoghurt. }\end{array}$ \\
\hline
\end{tabular}

Dibuktikan dengan kutipan wawancara

salah satu informan pendukung : "Kalo buat makan makanan dari tepung itu memang masih kelihatan dikasih ke anaknya, tapi kalo buat susu itu biasanya dikasih susu kedele sih keliatannya. Cuma kalo jajan itu masih kurang diawasi jadi masih semaunya anak aja." (Informan Pendukung 1 Guru Kelas)

Berdasarkan hasil form Food Frequency Quetionnaire (FFQ) Qualitative dapat disimpulkan bahwa dari 6 subjek penelitian kebiasaan makannya masih terdapat bahan makanan yang berasal dari tepung, baik itu dikonsumsi dalam frekuensi yang sangat sering maupun jarang.
Kemudahan untuk mendapatkan informasi yang tepat dan mengetahui dasar ilmu dibalik diet mungkin dapat membantu orang tua mengerti prosesnya lebih baik karena tanpa kepatuhan terhadap diet, kekuatan dari diet tersebut tidak akan terlihat (Washnieski, 2009). Menurut Washnieski (2009) ada beberapa rintangan / hambatan dalam upaya menerapkan diet GFCF diantaranya adanya perlawanan dari anak, pembatasan diet yang membuat anak sulit untuk makan masalah lingkungan 
sekolah, orang tua tidak tahu cara menyiapkan, makanan yang bebas kasein dan gluten, tidak tahu dimana harus menemukan sumber yang dapat membantu untuk mengimplementasikan diet, dan sebagainya. Hal-hal tersebut dapat menjadi salah satu faktor yang tidak mendukung orang tua dalam menerapkan diet GFCF. Hal ini sebanding bahwa indikator kepatuhan orang tua dalam penelitian ini dilihat dari bagaimana perilaku orang tua tersebut dalam mengimplementasikan diet yang meliputi kemampuannya dalam memilih makanan untuk anak, pengawasannya terhadap asupan makan anak, dan konsisten dalam menerapkan diet GFCF. Dalam hal ini, seorang ibu sangat dituntut untuk dapat bersikap selektif dalam mengatur pola makan anak dan dapat memilahmilah jenis makanan yang diolahnya, tidak hanya kualitas yang diutamakan tetapi juga kandungan zat gizi yang ada didalam bahan makanan itu (Koka, 2011).

Selain itu, ada beberapa faktor yang mungkin dapat mempengaruhi perilaku orang tua dalam menerapkan diet GFCF pada anaknya. Salah satunya perilaku anak autis yang mungkin dapat menjadi hambatan orang tua seperti perilaku tantrum (ledakan emosi) dan picky eaters (pilih-pilih makanan) yang muncul pada anak yang cenderung membuat orang tua mengalah sehingga mempengaruhi perilaku orang tua itu sendiri dalam menerapkan diet GFCF pada anaknya (Reilly, 2008). Berdasarkan dengan hasil penelitian Sofia (2012) yaitu sebanyak 85\% orang tua yang tidak patuh dalam menerapkan diet GFC, hal ini menunjukkan adanya ketidaktepatan orang tua dalam penerapan diet GFCF pada anak autisme. Tidak semua makanan/ minuman yang mengandung kasein dan gluten dihilangkan dalam menu makan anaknya. Protein kasein dan glutein yang terkandung dalam makanan/ minuman yang dikonsumsi anak autisme masuk kedalam tubuh dan akan berpengaruh pada sistem tubuh, termasuk fungsi otak yang akhirnya mempengaruhi emosi anak, sehingga munculah perilaku tantrum 
yang akan semakin menyulitkan orang tua dalam menerapkan diet GFCF.

Menurut Washnieski (2009) sebagian besar orang tua mengakui bahwa makanan yang dilarang kadangkadang diberikan kepada anak-anak secara sengaja, dan umumnya makanan yang berbahan dasar dari tepung dan susu adalah makanan yang paling disuka oleh anak, sehingga jika anak menangis ingin makan makanan tersebut ibu merasa kasihan dan akhirnya diberikan walaupun sebenarnya ibu sudah mengetahui makanan apa saja yang menjadi pantangan untuk anak autis.

\section{KESIMPULAN}

Pemahaman ibu saat ini sudah cukup baik dan mengetahui makanan apa yang seharusnya dibatasi, namun untuk penerapannya ibu belum bisa melakukan pembatasan makanan berbahan dasar gluten dan kasein secara ketat. Penerapan diet GFCF ini dirasa sulit oleh ibu karena anak cenderung lebih suka pilih pilih makanan (picky eater) dan anak memiliki sifat tantrum (mudah marah), kebiasaan makan subjek penelitian masih terdapat bahan makanan yang berasal dari tepung, baik itu dikonsumsi dalam frekuensi yang sangat sering maupun jarang.

Pihak sekolah sebaiknya melakukan pengawasan jajanan bagi anak autis dengan cara membatasi produk jualan makanan berbahan dasar tepung dan susu di kantin sekolah dan pihak sekolah tidak hanya memberikan pengetahuan dan konsultasi saja kepada orangtua namun melakukan monitoring dan evaluasi mengenai pengetahuan orangtua. Sebaiknya orangtua anak autis pun lebih meningkatkan pemahaman mengenai diet GFCF serta penerapannya dengan cara mengikuti seminar atau workshop kesehatan mengenai pola makan anak autis serta membaca buku atau mencari di internet jenis makanan atau masakan selain menggunakan bahan makanan gluten dan kasein yang kaya akan zat gizi.

\section{PUSTAKA}

Judarwanto W. 2006. Pencegahan Autis pada Anak, http://www.alergianak.bravehost.com [Diakses 2 April 2016]

Koka EM. 2011. Perilaku ibu tentang pemberian makan dan status gizi anak 
autism di kota Binjai tahun 2011. http://repository.usu.ac.id [Diakses tanggal 24 September 2016]

Kusumayanti D, Suiraoka, Nursanyoto. 2005, Hubungan antara Konsumsi Casein, Gluten dan Pola Aktivitas yang Khas pada Anak Penyandang Autis di Denpasar. [Prosiding] Temu Ilmiah Kongres XII Persagi.

Latifah RE. 2004. Studi Konsumsi dan Status Gizi pada Anak Penyandang Gangguan Spektrum Autisme di Kota Bogor [Laporan Hasil Penelitian] Bogor: Fakultas Pertanian, Institut Pertanian.

Mashabi NA dan Tajudin N R. 2009. Hubungan antara pengetahuan gizi ibu dengan pola makan anak autis, Makara Kesehatan, 13 (2) : 84-86.

Priyatna A. 2010. Amazing Autisme! Memahami, Mengasuh, dan Mendidik Anak Autisme. P.T Gramedia, Jakarta

Ratnawati H. 2003. Leaky gut sebagai penyebab gangguan gastrointestinal pada ASD. Jurnal Bagian Histologi, Fakultas Kedokteran, Universitas Kristen Maranatha, 2 (2) : 46-48

Reilly JT, Amaral SC, Zebrowski PP. 2008. Addressing feeding disorders in children on the autism spectrum in school-based settings. http://web.ebscohost.com [Diakses tanggal 24 September 2016]

Sofia AD. 2012. Kepatuhan Orang Tua dalam Menerapkan Terapi Diet Gluten Free Casein Free pada Anak Penyandang Autisme di Yayasan Pelita Hafizh dan SLBN Cileunyi Bandung, Laporan Hasil Penelitian, Fakultas Ilmu Keperawatan, Universitas Padjadjaran, Bandung.

Washnieski G. 2009. Gluten-free and Caseinfree Diets as a Form of Alternative Treatment for Autism Spectrum Disorders.

http://www2.uwstout.edu/content

[Diakses tanggal 24 September 2016] 